\title{
З ФОНДІВ ПЕДАГОГІЧНОГО МУЗЕЮ УКРАЇНИ
}

\author{
До уваги читачів журналу! \\ Пропонуємо інформацію про видані Педагогічним музеєм України \\ НАПН України книги у двох видавничих серіях: «Бібліофонд Педагогічного \\ Музею» та «Педагогічні републікації (http://pmu.in.ua/books).

\section{«ПЕДАГОГІЧНІ РЕПУБЛІКАЦІЇ»}

Започаткована Педагогічним музеєм України у 2014 році видавнича серія «Педагогічні републікації» має на меті популяризувати і актуалізувати маловідомі або призабуті праці вчених, педагогів, освітніх діячів минулого.

Основним джерелом републікацій є матеріали, що зберігаються у фондах музею. Серію адресовано вченим, аспірантам, докторантам, викладачам вищих навчальних закладів, студентам та всім, хто цікавиться історією української освіти.
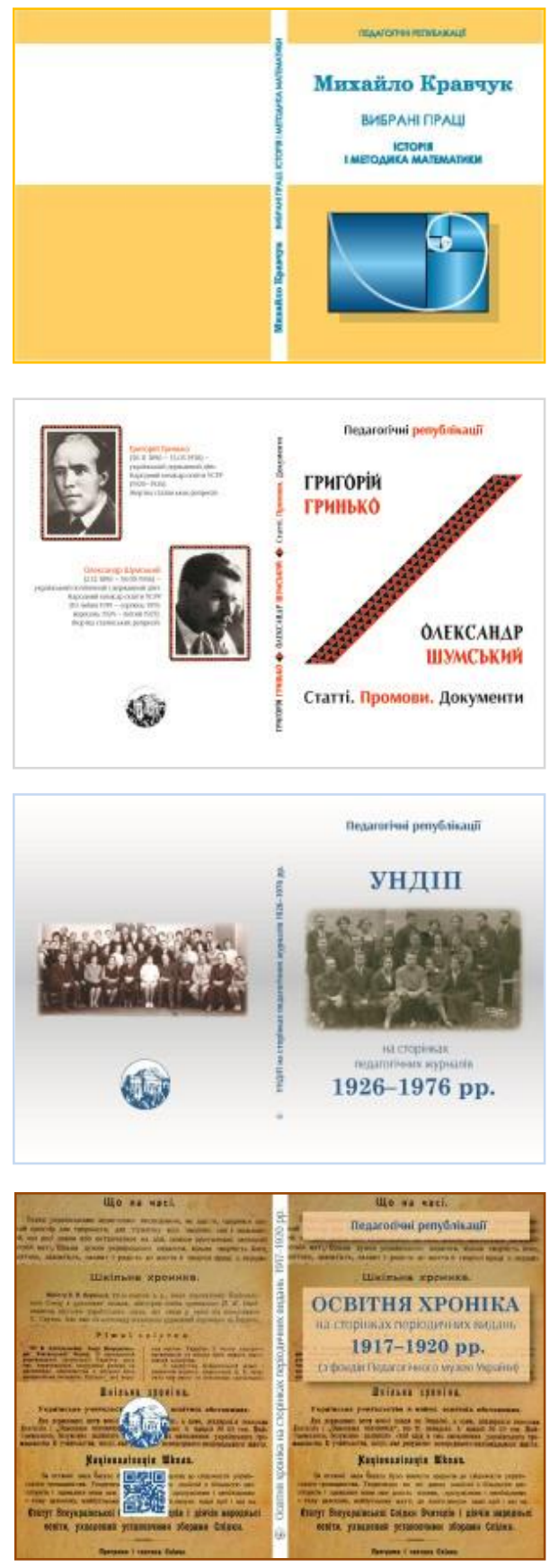

Михайло Кравчук. Вибрані праці. Історія і методика математики / Національний технічний університету України «КПІ», Педагогічний музей України; [упоряд.: Вірченко Н. О., Гайдей В. О., Міхно О. П.]. - К. : НТУУ «КПІ», ПМУ, 2014. - 252 с. - (Сер. «Педагогічні републікації» ; вип. 1).

Григорій Гринько. Олександр Шумський : Статті. Промови. Документи / НАПН України, Педагогічний музей України ; [укладачі : В. О. Гайдей, О. П. Міхно ; наук. консультант О. В. Сухомлинська]. - К. : ПМУ, 2015. - 144 с. - (Сер. «Педагогічні републікації» ; вип. 2).

УНДІП на сторінках педагогічних журналів 1926-1976 pp. / НАПН України, Педагогічний музей України ; [укладачі : В. О. Гайдей, О. П. Міхно ; наук. консультант О. В. Сухомлинська]. - К. : ПМУ, 2016. - 212 с. - (Сер. «Педагогічні републікації» ; вип. 3).

УНДІП на сторінках педагогічних журналів 1926-1976 pp. / НАПН України, Педагогічний музей України ; [укладачі : В. О. Гайдей, О. П. Міхно ; наук. консультант О. В. Сухомлинська] [Розширена електронна версія]. - К. : ПМУ, 2016. - 355 с. (Сер. «Педагогічні репуб-лікації» ; вип. 3).

Освітня хроніка на сторінках періодичних видань 1917-1920 pр. (з фондів Педагогічного музею України) / Педагогічний музей України ; [укладачі : В. О. Гайдей, О. П. Міхно ; наук. консультант О. В. Сухомлинська]. - Київ : ПМУ, 2017. 182 с. - (Сер. «Педагогічні републікації» ; вип. 4). 


\section{«БІБЛІОФОНД ПЕДАГОГІЧНОГО МУЗЕЮ»}

Видавнича серія «Бібліофонд Педагогічного музею» започаткована у 2015 році і адресована дослідникам української культури, історикам, педагогам, книгознавцям, бібліографам, працівникам музеїв.

Основна мета серії - оприлюднення результатів наукового опрацювання фондів музею у формі каталогів книжкових музейних колекцій.
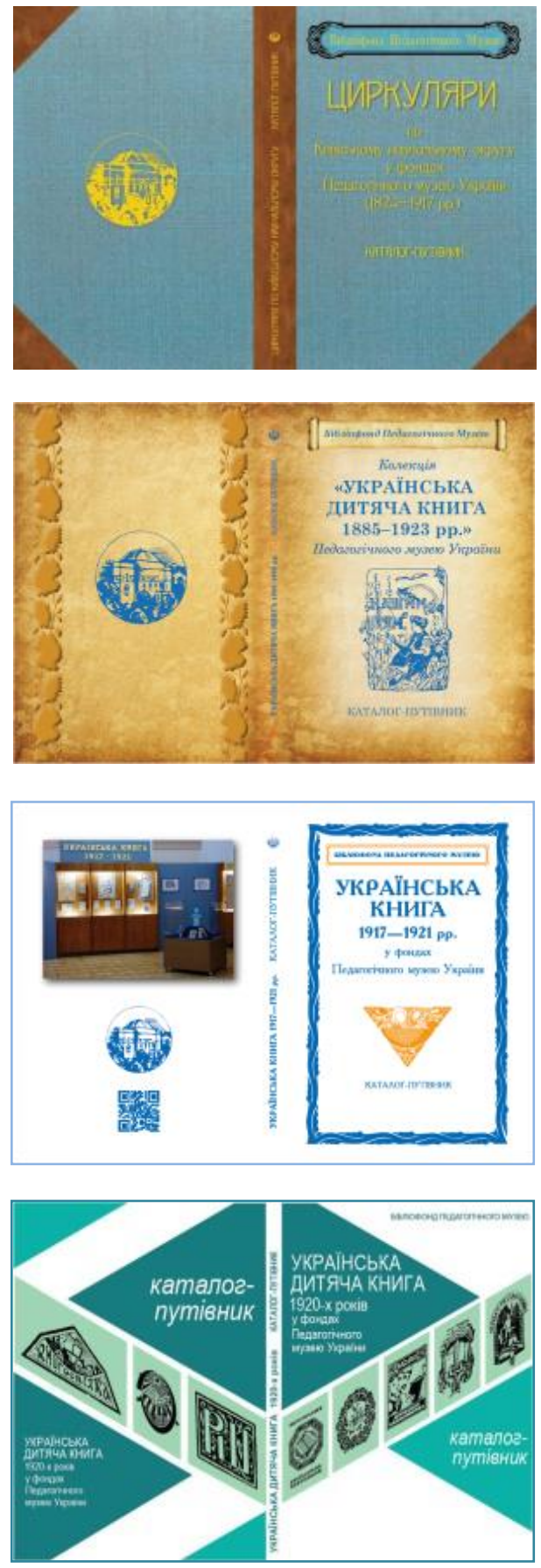

Українська дитяча книга 1920-х років у фондах Педагогічного музею України : Каталог-путівник / Педагогічний музей України ; [укладачі : В. О. Гайдей, О. П. Міхно ; наук. консультант О. В. Сухомлинська]. - Київ : ПМУ, 2018. - 116 с. ; іл. (Сер. «Бібліофонд Педагогічного Музею» ; вип. 4).

3 метою надання зацікавленому читачеві якнайширшого доступу до видавничих серій: «Бібліофонд Педагогічного Музею» та «Педагогічні републікації» видання виходять у двох варіантах: друкованому та електронному та розміщені на сайті Педагогічного музею України: http://pmu.in.ua/books. 